\title{
Distribution of HLA-B27 in patients with juvenile rheumatoid arthritis
}

\author{
H. MITSUI*, T. JUJI $\dagger$, H. SONOZAKI*, H. SEKI*, AND N. WATANABE $\ddagger$
}

From the Rheumatology Unit, Department of Orthopaedic Surgery*, and Department of Blood Transfusion Service, University of Tokyo t; Department of Paediatrics, University of Kyorin, Tokyo, Japan+

SUMMARY HLA antigens were examined in 27 patients with juvenile rheumatoid arthritis. HLA B27 was found in none. The result was different from most other previously reported studies. Th⿸户 most likely explanation for this difference is the possibility that some patients with juvenile anky? losing spondylitis may have been included among the patients in the other studies.

Recently there has been an extensive search for an association between histocompatibility antigens (HLA) and specific diseases (Schlosstein et al., 1973). Rachelefsky et al. (1974) showed that HLA-B27 was found in $42 \%$ of all juvenile rheumatoid arthritis (JRA) patients examined. This report prompted us to investigate whether a similar relationship existed in Japanese patients.

\section{Materials and methods}

27 patients ( 7 males, 20 females) with JRA admitted to Tokyo University Hospital were studied. All were Japanese, and in all onset of the disease occurred before the age of 16 years. Diagnosis was based on the criteria (Brewer et al., 1973) for classification of JRA adopted by the American Rheumatism Association (Table 1).

Each patient was carefully observed and underwent a complete examination. Radiological examination was performed on affected joints and on the sacroiliac joints. Duration of follow-up ranged from 1 to 20 years, with $50 \%$ studied for more than 10 years.

Accepted for publication May 11, 1976

Correspondence to Dr. H. Mitsui, Department of Orthopaedic Surgery, Faculty of Medicine, University of Tokyo, Hongo, Tokyo, Japan
HLA typing was performed by the microdroplet lymphocyte cytotoxicity test. 22 HLA antigens were examined in 181 normal Japanese controls and it 27 patients with JRA. 41 patients with ankylosing spondylitis were also examined as a control group. The same antisera was used in typing both patientş and controls.

\section{Results}

The incidence of the first and second sublocus antigens in our patients was compared to those in the controls (Table 2). Although HLA-B27 wa found in $74 \%$ of ankylosing spondylitis patients? none of the JRA patients or normal controls showed this phenotype.

\section{Discussion}

According to the reports by Rachelefsky et $a \stackrel{B}{B}$ (1974), Carpenter et al. (1973), Buc et al. (1974), and Sturrock et al. (1974), HLA-B27 was found more frequently in patients with JRA than in the normad population. However, Gibson et al. (1975) recently reported on the association between HLA antigen and the disease; none was found, but HLA-B7 was found more frequently in patients with JRA demono strating tenosynovitis than in the population with

Table 1 Clinical characteristics of patients with JRA

\begin{tabular}{|c|c|c|c|c|c|c|}
\hline & No. of patients & Males & Females & $\begin{array}{l}\text { Mean age at } \\
\text { onset }(y r)\end{array}$ & $\begin{array}{l}\text { Positive } \\
\text { rheumatoid } \\
\text { factor } \\
\text { (no. of patients) }\end{array}$ & Uveitis \\
\hline $\begin{array}{l}\text { Acute type (Still's disease) } \\
\text { Polyarticular (adult type) } \\
\text { Monarticular }\end{array}$ & $\begin{array}{r}6 \\
16 \\
5\end{array}$ & $\begin{array}{l}2 \\
3 \\
2\end{array}$ & $\begin{array}{r}4 \\
13 \\
3\end{array}$ & $\begin{array}{l}4 \cdot 2 \\
7 \cdot 8 \\
7 \cdot 0\end{array}$ & $\begin{array}{l}0 \\
4 \\
1\end{array}$ & $\begin{array}{l}1 \\
2 \\
3\end{array}$ \\
\hline Total no. of patients & 27 & 7 & 20 & & 5 & 6 \\
\hline & & & 86 & & & \\
\hline
\end{tabular}


Table $2 H L A$ antigen incidence in controls and patients with JRA and ankylosing spondylitis

\begin{tabular}{|c|c|c|c|}
\hline$H L A$ & $\begin{array}{l}\text { Healthy } \\
\text { population }(\%) \\
(n=181)\end{array}$ & $\begin{array}{l}\text { Patients with } \\
\text { JRA }(\%) \\
(n=27)\end{array}$ & $\begin{array}{l}\text { Patients with } \\
\text { ankylosing } \\
\text { spondylitis } \% \\
(n=41)\end{array}$ \\
\hline \multicolumn{4}{|c|}{ HLA-A locus } \\
\hline A1 & 1.66 & $3 \cdot 7$ & $2 \cdot 86$ \\
\hline A2 & $33 \cdot 70$ & 37.04 & $37 \cdot 14$ \\
\hline A3 & $1 \cdot 10$ & 0 & $2 \cdot 86$ \\
\hline A9 & $42 \cdot 54$ & $70 \cdot 37$ & $54 \cdot 29$ \\
\hline A 10 & 16.89 & $33 \cdot 33$ & $17 \cdot 14$ \\
\hline A11 & $12 \cdot 15$ & 25.93 & $25 \cdot 71$ \\
\hline A28 & 0 & 0 & $5 \cdot 71$ \\
\hline Aw33 & $14 \cdot 81$ & 9.09 & $2 \cdot 86$ \\
\hline \multicolumn{4}{|c|}{ HLA-B locus } \\
\hline B5 & $30 \cdot 39$ & 25.93 & $42 \cdot 86$ \\
\hline B7 & 11.05 & $14 \cdot 81$ & $14 \cdot 29$ \\
\hline B8 & $1 \cdot 10$ & 0 & 0 \\
\hline $\mathrm{B} 12$ & 19.89 & $18 \cdot 52$ & $2 \cdot 86$ \\
\hline B13 & $1 \cdot 10$ & $3 \cdot 70$ & $2 \cdot 86$ \\
\hline B14 & 1.66 & 0 & 0 \\
\hline Bw 17 & 0 & 0 & 0 \\
\hline B27 & 0 & 0 & $74 \cdot 0$ \\
\hline Bw35 & 6.08 & $7 \cdot 41$ & 0 \\
\hline Bw40 & $18 \cdot 78$ & $55 \cdot 56$ & $14 \cdot 29$ \\
\hline Bw15 & 8.84 & $18 \cdot 52$ & 11.43 \\
\hline Bw16 & $2 \cdot 21$ & 0 & 0 \\
\hline Bw21 & 0.55 & 0 & 0 \\
\hline Bw22 & $18 \cdot 78$ & $22 \cdot 22$ & $14 \cdot 29$ \\
\hline
\end{tabular}

JRA with no tenosynotitis, but there was no association with HLA-B27, a finding attributed by the authors to the exclusion of cases of ankylosing spondylitis from their study.

The discrepancy between the findings of most of the above-mentioned authors and our own may be explained by some racial differences between Japanese and Caucasians; however, it is more likely that some patients with juvenile ankylosing spondylitis may have been included among the Caucasian groups. The incidence of HLA-B27 in normal Japanese controls and in 27 patients with JRA was $0 \%$, while it was $74 \%$ in Japanese patients with ankylosing spondylitis. These results suggest that the second explanation is the more likely one. We have seen some cases of juvenile ankylosing spondylitis where the early clinical features were almost indistinguishable from those of JRA, but after long-term follow-up these patients showed definite clinical features of ankylosing spondylitis. In fact, diagnosis of ankylosing spondylitis or Reiter's syndrome eliminated those patients from our study. 2 patients with juvenile ankylosing spondylitis were so eliminated after long-term follow-up. The increased frequency of HLA-B27 reported in other studies could indicate that patients with juvenile ankylosing spondylitis were not excluded from the group of JRA patients.

HLA-B27 was never found in our 181 normal controls. We have typed HLA antigens in over 3000 normal persons or patients with disorders other than rheumatic diseases. However, HLA-B27 has been found in only 6 of these $(0.2 \%)$. Saito et al. (1975) reported that the incidence of HLA-B27 was $1.5 \%$ in 200 normal Japanese and Tsuji and Fukunishi (1973) found $0 \%$ in 248 . These reports show that the incidence of HLA-B27 in the Japanese population is much lower than in Caucasians. This may be one of the reasons why in ankylosing spondylitis, also, the incidence of HLA-B27 is lower in Japanese patients. The low incidence of ankylosing spondylitis in Japan may be due to the low incidence of HLA-B27 in the Japanese population. However, Amor et al. (1974) and Dick et al. (1975) reported recently that the incidence of HLA-B27 in Caucasian patients with ankylosing spondylitis was $81 \%$ and $82.4 \%$, respectively. These figures are closer to ours.

\section{References}

Amor, B., Feldman, J. L., Delbarre, F., Hors, J., Beaujan, M. M., and Dausset, J. (1964). HL-A antigen W27-a genetic link between ankylosing spondylitis and Reiter's syndrome? New England Journal of Medicine, 290, 572.

Brewer, E. J., Jr., Bass, J. C., Cassidy, J. T., Duran, B. S., Fink, C. W., Jacobs, J. C., Markowitz, M., Reynolds, W. E., Schaller, J., Stillman, J. S., and Wallace, S. L. (1973). Criteria for the classification of juvenile rheumatoid arthritis. Bulletin on Rheumatic Diseases, 23, 712-719.

Buc, M., Nyulassy, S., Stefanovic, J., Michalko, J., and Mozolva, D. (1974). HL-A system and juvenile rheumatoid arthritis. Tissue Antigens, 4, 395-397.

Carpenter, C. B., Zschaeck, D., Bianco, N., Stillman, J. S., and Schur, P. H. (1973). Distribution of HL-A antigens in patients with juvenile rheumatoid arthritis (JRA). Federation Proceedings, 32, 1027.

Dick, H. M., Sturrock, G. K., Goel, G. K., Henderson, N. G., Ganesi, B., Rooney, P. J., Dick, W. C., and Buchanan, W. W. (1975). The association between HL-A antigens, ankylosing spondylitis and sacro-iliitis. Tissue Antigens, 5, 26-32.

Gibson, D., Carpenter, C., Stillman, S., and Schur, P. (1975). Re-examination of histocompatibility antigens found in patients with juvenile rheumatoid arthritis. New England Journal of Medicine, 293, 636-638.

Rachelefsky, G., Terasaki, P. I., Katz, R., and Stiehm, E. R. (1974). Increased prevalence of W27 in juvenile rheumatoid arthritis. New England Journal of Medicine, 290, 892893.

Saito, S., Naito, S., Toyoda, K., Konomi, K., Yamamoto, H., Nishimura, M., and Arakawa, K. (1975). A study on HL-A system in Japanese. Tissue Antigens, 5, 217-225.

Schlosstein, L., Terasaki, P. I., Bluestone, R., and Pearson, C. M. (1973). High association of an HL-A antigen, W27, with ankylosing spondylitis. New England Journal of Medicine, 288, 704-706.

Sturrock, R. D., Dick, H. M., Henderson, N., Canesi, B., Lee, P., and Dick, W. C. (1974). Association of W27 and $\mathrm{AJ}$ in juvenile rheumatoid arthritis and ankylosing spondylitis. Journal of Rheumatology, 1, 269-273.

Tsuji, K., and Fukunishi, T. (1973). Distribution of HL-A antigens in the solitary islands of Japan. International Congress Series, No. 300, p. 2. Excerpta Medica, Amsterdam. 